Aletria, Belo Horizonte, v. 31, n. 3, p. 75-96, 2021

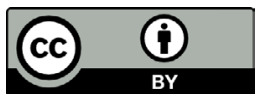

\title{
Autoexílio e pátria literária em Los Eunucos Inmortales de Oswaldo Reynoso
}

\section{Self-exile and Literary Homeland in Los Eunucos Inmortales by Oswaldo Reynoso}

\section{Lara Poenaru}

Universidade Federal de Minas Gerais (UFMG), Belo Horizonte, Minas Gerais / Brasil larapoenaru@gmail.com

https://orcid.org/0000-0002-9404-536X

Rômulo Monte Alto

Universidade Federal de Minas Gerais (UFMG), Belo Horizonte, Minas Gerais / Brasil romulomontealto@gmail.com

http://orcid.org/0000-0002-5859-9867

Resumo: Este artigo discute os reflexos do autoexílio no livro Los Eunucos Inmortales (1995), do escritor peruano Oswaldo Reynoso. Parte da hipótese defendida por Torres (2016) de que a prosa de Reynoso, após o exílio, pode ser lida desde uma segunda onda criativa, caracterizada pela linguagem poética que visa ao descobrimento da identidade, e propõe analisar três fatores de inflexão do romance: o paralelismo entre Lima e Pequim na descrição dos eventos históricos violentos, a construção da imagem do estrangeiro e o viés antropológico adotado para se pensar pátria e identidade. Se anteriormente Reynoso buscava a liberdade a partir da crítica visceral ao capitalismo, agora muda o objeto de sua procura vital, desencadeada após a frustração do regime maoísta. Para o narrador, a liberdade, agora entendida como felicidade, passa a se encontrar na literatura e não na realidade, o que o leva a propor que sua identificação nacional não se alinha mais à pátria geográfica, mas à pátria literária.

Palavras-chave: Literatura peruana; exílio; pátria literária; literatura e sociedade. 


\begin{abstract}
This paper discusses the reflexes of self-exile in the book Los Eunucos Inmortales (1995) written by Peruvian author Oswaldo Reynoso. Considering the hypothesis defended by Torres (2016) that Reynoso's prose, after exile, can be read from a second creative wave, characterized by the poetic language aimed at the discovery of identity, three novel innovations were analyzed: parallelism between Lima and Beijing; the construction of the foreigner's image; the anthropological bias adopted to think of homeland and identity. If Reynoso previously sought freedom from a visceral criticism of capitalism, now the object of his vital search, triggered after the frustration of the Maoist regime, changes. For the narrator, freedom, now understood as happiness, comes to be found in literature and not in reality, which leads him to propose that his national identification is no longer aligned with the geographical homeland, but with the literary homeland.
\end{abstract}

Keywords: Peruvian literature; exile; literary homeland; literature and society.

La patria que no está en ninguna parte

esa es mi verdadera patria

(Oswaldo Reynoso, 2005b)

La búsqueda de una divinidad concreta, humana y bella, que me enseñe el goce pleno de la libertad

(Oswaldo Reynoso, 2005b)

\title{
Introdução
}

Oswaldo Reynoso (1931-2016) é reconhecido pela crítica contemporânea como um dos narradores peruanos de maior relevância no país, consolidando-se como referente de uma prosa urbana inaugural marcada por uma vertente violentamente realista, na qual inovações nos planos formal e temático se engendram, produzindo um quadro irreverente e quase lúdico sobre a desigual experiência moderna em Lima. Em suas obras, destaca-se o desenvolvimento de uma narrativa que parte de uma percepção ultra humanizadora das personagens, na qual se ampliam e se complexificam seus traços (a)morais, fugindo de um maniqueísmo redutor.

Ricardo González Vigil (2008, p. 192), em sua antologia da narrativa peruana recente, ao analisar a produção de Oswaldo Reynoso, sustenta que o autor constrói ao longo de suas obras uma espécie de "religião erótica e estética", que busca sua dimensão divina a partir do gozo pleno da liberdade, alcançado através das experiências proibidas, 
via delito, delinquência e transgressão. Jorge Eslava (2005) destaca que as obras que combinam, no mesmo plano, sordidez e injustiça com desejo e felicidade, oferecem um novo caminho para se (re)conhecer a experiência humana. Nesse sentido, nota-se que, nas obras de Reynoso, o corpo torna-se sujeito e objeto das experiências mais cruéis e prazerosas experimentadas pelas personagens, e é através desse processo catártico de exploração de limites entre o sublime e o terrível, que se encontra o cerne do projeto estético-literário deste autor.

Uma das causas que justificariam o renovado interesse na produção de Reynoso é a profunda mudança no horizonte de recepção de sua produção, que revisou seu valor literário, especialmente nos fins dos anos de 1990. O aparecimento de uma crítica menos conservadora, a formação de um público leitor especializado que revalida suas obras, $o$ espaço dado pelas mídias para o renascimento do autor após seu autoexílio e o trabalho de mentor de novos escritores, que vieram a se tornar autores de prestígio na atualidade, são algumas das causas que impulsionam e validam a releitura das produções de Reynoso, no âmbito da crítica.

Com o objetivo de contribuir para a ampliação do acesso à produção literária deste autor no âmbito brasileiro, bem como refletir criticamente sobre os limites e alcances dessa obra para a teoria literária, propõe-se no presente trabalho uma discussão sobre o romance Los Eunucos Inmortales, lançado em 1995, alguns anos após o retorno do escritor ao Peru, depois de um período de doze anos em autoexílio na China. Considerando a hipótese defendida por Torres (2016) de que, pós-1989, a produção de Reynoso deve ser pensada sob uma segunda incursão crítica, mais afastada de questões ideológicas e mais próxima da subjetividade e da poética, busca-se analisar a guinada criativa observada na obra autobiográfica a partir de três pontos: o paralelismo entre Lima e Pequim na descrição dos eventos violentos de ambas as cidades, a construção da imagem do estrangeiro e o viés antropológico adotado para se pensar pátria e identidade. A partir dos três pontos abordados, objetiva-se compreender em que medida vida e obra / autoexílio e romance autobiográfico se tangenciam simetricamente na construção de uma nova perspectiva de identidade nacional: a pátria literária.

\section{A trajetória criativa de Reynoso}

Em 1955, Reynoso publica sua primeira obra, a coletânea de poesias Luzbel (1955) e, somente seis anos depois, lança seu primeiro livro em prosa, Los inocentes (1961), que viria a se consolidar, muitas 
décadas depois, como um best seller. Em 1965, Oswaldo Reynoso publica seu primeiro romance, En Octubre no hay Milagros. A obra, como sugere Jorge Eslava (2005), apresentava um quadro expressionista que exibia a deterioração moral da sociedade peruana, tendo como pano de fundo uma procissão religiosa tipicamente limenha, a procissão do Senhor dos Milagres (ESLAVA, 2005, p. 16).

Em 1965, após a publicação de En Octubre no hay Milagros, o crítico José Miguel Oviedo publica uma resenha intitulada "Reynoso o la fascinación por el abyecto", cujo título já antecede o tom da crítica. Oviedo se incomoda com as cenas pornográficas, consideradas excessivas, assim como o emprego de gírias e palavrões, que, segundo ele, não enriqueceram a obra.

Trataremos o romance de Reynoso pelo que ele tenta ser: uma obra literária; e o seu autor pelo que ele efetivamente é: um autor fascinado pela abjeção, morbosidade e imundície [...] esse tipo de narrador escandaloso e coprolálico que apenas espreita nossa literatura. [...] Nesse proceder de acumulação, pervertido entre nojo e prazer, Reynoso parece se incluir na linha condenada de certos escritores-pornógrafos, como Henry Miller (REYNOSO, 2006, p. 397, tradução nossa) ${ }^{1}$.

Marco Martos, também em 1965, publica no jornal La Tribuna uma crítica na qual elogia o tratamento dado à temática urbana e seu valor de denúncia; contudo, não prevê a transcendência do livro dentre os cânones peruanos, especialmente em razão da linguagem procaz que desmerece o relato (REYNOSO, 2006, p. 401). Cornejo Polar, em 1966, no jornal El Pueblo, apesar de reconhecer as inovações do livro no plano temático, no ritmo da narração, no uso das figuras literárias e no vigor e originalidade da linguagem, critica o ingrediente predominantemente sexual e prevê o "mal uso" que muitos leitores farão da obra (REYNOSO, 2006, p. 405). Em resposta às críticas, Mario Vargas Llosa escreve em 1966 o artigo "¿Pero qué diablos quiere decir pornografía?”, no qual associa a concepção conformista e provinciana da literatura a um sintoma

\footnotetext{
1 "Trataremos la novela de Reynoso con lo que intenta ser: una obra literaria; y a su autor como lo que evidentemente es: un autor fascinado por la abyección, la morbosidad y la inmundicia (...) ese tipo de narrador escandaloso y coprolálico que apenas si asoma en nuestra literatura. (...) En este proceder por acumulación, enfangado entre el asco y el placer, Reynoso parece ubicarse en la línea condenada de ciertos escritores-pornógrafos, Henry Miller entre ellos."
} 
do subdesenvolvimento cultural do Peru. Para o autor, no entanto, a narração, em vários momentos, parece preferir o documental ao ficcional, o que impacta negativamente na qualidade da obra.

Reynoso, em entrevista, relembra as respostas violentas das instituições conservadoras: "quando publiquei En Octubre no hay Milagros a coisa cresceu mais. Chegaram a queimar o livro na procissão. Inclusive, enviaram um memorial ao Ministério de Educação, pedindo que anulassem meu título de docente" (REYNOSO, 2011, p. 39, tradução nossa $)^{2}$. O período mais turbulento da recepção de suas obras, que foram alvo de censura não oficial e ataques por parte de uma grande parcela de leitores, fixa o estigma de obra e autor pornográficos, imagem que levou um bom tempo para ser revista. O segundo romance de Reynoso, El Escarabajo y el Hombre (1970), é editado de forma quase clandestina e recebe da crítica apenas uma breve nota em uma revista acadêmica.

Em 1965, em sua intervenção durante o Primeiro Encontro de Narradores Peruanos, evento organizado pela Casa de Cultura de Arequipa, do qual participaram José María Arguedas, Ciro Alegría, Mario Vargas Llosa, dentre outros, Oswaldo Reynoso relata as diversas perseguições sofridas naquele momento. Após ser reitor da Universidade Nacional de Educação Enrique Guzmán y Valle (La Cantuta), Reynoso é demitido quando Manuel Odría assume o governo. Posteriormente contratado pelo Colégio Marista de San Isidro, também foi demitido após tentar organizar um sindicato de professores de colégios particulares. À época do Encontro, ainda contratado pela Universidade de Huamanga, afirmava ser aquele um dos últimos redutos de liberdade que restavam no país (POLAR, 1986, p. 56).

Encontrando-se em um cenário laboral adverso, Reynoso viaja à China, em um período de autoexílio, em 1977, a convite do governo chinês, para trabalhar como corretor de estilo, retornando ao Peru apenas em 1989. Durante a temporada de doze anos no país comunista, que nesse intervalo passa por um processo de reabertura política, muitas mudanças ocorrem em suas posições políticas mantidas até aquele momento, especialmente no que se refere ao teor engajado de suas opiniões públicas, notadamente próximas às tendências mais radicais do socialismo maoísta. Pode-se afirmar que, após seu autoexílio, Reynoso adota uma postura

2 “Cuando publiqué En Octubre no hay Milagros la cosa se extendió más. Llegaron a quemar el libro en la procesión. Incluso elevaron un memorial al ministerio de Educación pidiendo que anulen mi título de docente." 
comedida ao tratar da luta armada no Peru, conforme observado em suas entrevistas a partir dos anos 1990, e a temática social abordada em seus primeiros livros dá lugar a reflexões individuais no campo subjetivo, esotérico e até onírico em suas obras posteriores.

Em 1993, seu terceiro romance é publicado, já em sua volta ao Peru. En Busca de Aladino mescla a narrativa de Sherazade com a busca do protagonista. Em 1995, Reynoso publica Los Eunucos Inmortales (1995), romance autobiográfico em que seu alter ego, professor O, narra em primeira pessoa os acontecimentos imediatamente anteriores ao Massacre da Praça da Paz Celestial, testemunhado durante seu período de autoexílio na China. Posteriormente, publica El Goce de la Piel (2005), Las Tres Estaciones (2006), En Busca de la Sonrisa Encontrada (2012), El Gallo Gallina (2014), Arequipa Lámpara Incandescente (2014), e, postumamente, Capricho en Azul (2020).

Sua produção literária após o retorno ao Peru foi contemplada com o apreço dos novos críticos, que, através do processo de releitura de toda sua produção, reconhecem nela traços inaugurais, redefinindo seu lugar na história literária peruana ${ }^{3}$. Ricardo Vigil, um dos críticos literários de grande expressão no país, escreve uma resenha, em 2005, intitulada "La moral de la piel", na qual analisa o caráter "pornográfico" da escrita de Reynoso. O crítico retoma a discussão dos anos 1960, em que se questionava a menção excessiva de elementos relativos à sexualidade das personagens nas obras do autor, ressignificando o signo do abjeto para denominá-lo, agora, como a "pura moral da pele". Para ele, a proposta instaurada por Reynoso no âmbito da sexualidade das personagens é considerada uma sacralização do gozo terreno, na qual se entrelaçam a beleza do sexo e o culto à vocação artística (VIGIL, 2008, p. 191).

A partir dessa época, ocorre no panorama literário peruano uma revisão crítica sobre a importância da produção de Reynoso, cujo ponto alto encontramos em três momentos principais: em 2011, quando se comemoraram os 50 anos da publicação de Los Inocentes, o Centro Cultural de España (CCE) em Lima realizou a exposição $E l$ Tesoro de la Juventud, para a qual foram convocados diversos artistas (cartunistas, caricaturistas, ilustradores, coreógrafos), latino-americanos e espanhóis, para homenagear Oswaldo Reynoso. Buscando abordar a história daqueles adolescentes da década de 1960, para plasmá-la

3 Estes mesmos críticos, em 1994, já apontam para uma revisão do valor literário das obras de Reynoso, ao tecerem críticas favoráveis quando da reedição de En Octubre no hay Milagros. 
com outras linguagens artísticas, o evento revelava sua intenção de mostrar a permanente capacidade desta obra de continuar gerando novos significados, através de outras artes. O segundo momento se deu em 2013, com a realização da maior homenagem já recebida pelo autor: o Congresso Internacional Los Universos Narrativos de Oswaldo Reynoso, organizado pela Academia Peruana da Língua, pelo Instituto de Ciências Humanísticas da Faculdade de Letras da Universidade Nacional Mayor de San Marcos e pela editora San Marcos. O terceiro momento foi em 2015, quando a celebração teve como alvo a publicação de En Octubre no hay Milagros. O Colóquio Internacional En Octubre no hay Milagros. 50 años después, organizado pelo Instituto de Investigações Humanísticas da Faculdade de Letras da Universidade Nacional Mayor de San Marcos, reuniu pesquisadores do Peru e do exterior. Os três momentos destacam eventos que confirmam a atualidade e a relevância da produção de Reynoso para a crítica internacional.

\section{Um escritor comprometido}

Oswaldo Reynoso nunca propôs descolar vida e obra, nem mesmo apagar os traços identitários de seu repertório literário. Por isso, é fundamental analisar como as dimensões política e literária se entrelaçam em suas obras, para compreender a construção do romance Los Eunucos Inmortales e os caminhos que se tangenciam entre a experiência do autoexílio e a produção do seu romance autobiográfico. Quando Reynoso escreve as epígrafes de seus livros, mencionando nas entrelinhas suas influências literárias ou reforçando suas convicções políticas, o que aparece principalmente em suas entrevistas, ele está sugerindo um roteiro de leitura ideal de sua obra, que Umberto Eco (1993, p. 76), em seu livro Interpretação e Superinterpretação, chama de "intenção do autor empírico"; ali ele reconhece, de maneira pública e consciente, a filiação de sua produção a uma literatura comprometida.

Mas o que chamamos de literatura comprometida? Um referente comum dessa perspectiva crítica pode ser encontrada nas palavras de Jean-Paul Sartre (1961), filósofo existencialista francês que apoiou as lutas de libertações dos povos colonizados a partir da década de 1960, em especial do povo argelino; no prefácio da edição de $O s$ condenados $d a$ terra, de Franz Fanon, em setembro de 1961, Sartre assinalava o lugar da violência dos colonizados como um recurso possível e necessário em sua 
luta emancipatória, discurso que encontrava cabida entre todas as culturas do terceiro mundo, entre as quais sobressaiam as latino-americanas.

Em meados dos anos 1960, Reynoso reúne um grupo de novos escritores, críticos da arte dissociada de sua função social que, amparados nas ideias de Sartre, Marx e Mao Tse-Tung, reivindicam uma literatura do compromisso. Para tanto, lançam uma revista com o mesmo nome do grupo, Narración, em cujo manifesto, partem da trágica realidade peruana:

Nascemos em um dos países mais atrasados da Terra. Nossa vida constitui um milagre: temos mais de vinte anos. (No Peru mais de $50 \%$ perecem de fome antes de cumprir os 20 anos). Formamos uma pequena exceção: temos formação universitária e isso é um privilégio no Peru, onde há cerca de $60 \%$ de analfabetos. (REYNOSO et al., 1966 apud ESLAVA, 2005, p. 15, tradução nossa $)^{4}$

Para o grupo, o trabalho do artista vincularia seu compromisso artístico com a militância política e sua arte deveria estar a. Serviço do proletariado. Entre todos os aspectos teóricos relativos à produção literária, profundamente discutidos pelo grupo, há dois que se destacam: a função da literatura e o papel do escritor frente à sociedade. Sobre esses, pode-se afirmar que o fazer literário deveria ocorrer a partir da comunhão entre teoria e práxis, conforme afirma Reynoso, no Primeiro Encontro de Narradores Peruanos, em 1965, ao lançar seu primeiro romance:

No que se refere à minha atitude como homem e como escritor, tenho que dizer que estou a favor da violência, mas não uma violência irracional, e sim uma violência inteligente, organizada, para mudar o país. [...] No que se refere à minha criação literária, creio que ela é uma consequência direta da minha atitude vital, porque eu não posso pedir a um escritor comprometido com seu país que tenha apenas um compromisso teórico; creio que um escritor necessariamente deve ter uma militância política [...] no

\footnotetext{
4 "Hemos nacido en uno de los países más atrasados de la tierra. Nuestra vida constituye un milagro: tenemos más de veinte años. (En el Perú más del 50 por 100 perece de hambre antes de cumplir veinte años). Formamos una pequeña excepción: tenemos formación universitaria, y esto es un privilegio en el Perú, donde hay cerca del 60 por 100 de analfabetos."
} 
sentido de estar aderido de forma teórica e prática a uma ideologia. (POLAR, 1986, p. 57, tradução nossa) ${ }^{5}$

As afirmações contundentes de Reynoso a favor da revolução do proletariado; sua proximidade com Abimael Guzmán, futuro líder do movimento revolucionário Sendero Luminoso, que, nos anos 1960, era docente na mesma universidade onde Reynoso lecionava; sua temporada de três anos na Venezuela, naquele momento governada por um partido social democrata com tendências socialistas, e sua conhecida adesão à doutrina maoísta contribuem para que o escritor seja perfilado entre o rol de intelectuais considerados com potencial perfil subversivo aos olhos do governo peruano, que passa a persegui-lo, segundo suas palavras em entrevista a Enrique Planas (2011). Todos esses eventos, associados a uma crescente dificuldade de encontrar trabalho, contribuem para que, em 1977, ele aceite o convite de trabalho como corretor de estilo da agência de notícias Xinhua, empresa estatal do governo chinês, em um período de autoexílio que deveria ser inicialmente de doze meses, mas acabou se estendendo por doze anos.

Durante esse período, Reynoso testemunha a insatisfação popular com o autoritarismo do governo chinês e a reivindicação da abertura política do país, que culmina com o terrível episódio do Massacre da Praça da Paz Celestial (Tian'anmen), em 10 de junho de 1989. A China despertava econômica e socialmente em meio aos protestos que aparecem nos países comunistas a partir dos anos 1980, reivindicando mudanças políticas, o que levou os estudantes a se mobilizarem a favor de reformas democráticas no país. Após fracassadas tentativas do governo comunista de acabar com as manifestações, o mundo assistiu à entrada de tanques de guerra na Praça da Paz Celestial, durante a madrugada, resultando na tragédia na qual se estima que mais de dez mil pessoas tenham sido mortas e o movimento estudantil silenciado.

\footnotetext{
5 "En lo que se refiere a mi actitud como hombre y como escritor he de decir que estoy por la violencia, pero no una violencia irracional, sino una violencia inteligente, organizada, para cambiar el país. (...) En lo que se refiere a mi creación literaria, creo que es una consecuencia directa de mi actitud vital porque yo no puedo explicar a un escritor comprometido con su país que simplemente tenga un compromiso teórico; yo creo que el escritor comprometido necesariamente debe tener una militancia política (...) en el sentido de estar adherido teórica y prácticamente con una ideología." (POLAR, 1986, p. 57).
} 
Durante seu autoexílio, Reynoso também acompanha, à distância, o fim do governo militar de Morales Bermúdez (1975-1980), a ascensão de Belaúnde Terry (1980-1985) e o agravamento da crise econômica que se instaura no Peru, ao longo dos anos de 1980, quando suas principais matérias-primas de exportação sofrem uma queda brusca no valor de venda, a inflação e a dívida externa atingem níveis recordes e o desemprego aprofunda ainda mais as desigualdades estruturais. A convulsão social causada pela insatisfação com as medidas de austeridade adotadas pelo governo se expressa em greves e motins oriundos da sociedade civil; nesse ínterim, o país assiste ao surgimento de grupos armados, como Sendero Luminoso e o Movimento Revolucionário Túpac Amaru (MRTA), instaurando um conflito que deixou como saldo mais de sessenta mil mortos e cerca de duzentas mil pessoas expulsas de suas casas e terras. Na contraofensiva promovida a fim de restaurar sua governabilidade, o Estado convoca as Forças Armadas que, ao entrarem no conflito, potencializam os perversos resultados da contenda com um conjunto de ações que primam pela repressão e violência sobre as comunidades rurais. $\mathrm{O}$ relato de todos esses eventos pode ser conhecido nas páginas do Informe final da Comissão da Verdade e Reconciliação, publicado no ano de 2003.

Reynoso retorna ao Peru, em 1989 e, seis anos depois, em 1995, publica Los Eunucos Inmortales, no qual escreve sobre o período de 12 de maio a 10 de junho de 1989, notadamente os dias imediatamente anteriores ao massacre da Praça da Paz Celestial, em Pequim.

\section{Los Eunucos Inmortales}

Construído na forma de diário-memória, o romance é narrado em primeira pessoa, por um alter ego de Reynoso, o professor $\mathrm{O}$, peruano que fora contratado pelo governo chinês para trabalhar como revisor de estilo em uma agência internacional de notícias. Sua estrutura é dividida temporalmente e cada capítulo representa um dia, subdividindo-se em manhã, tarde, noite ou madrugada. A opção pela construção do romance nessa perspectiva, associada ao realismo das descrições, funciona como procedimento que, segundo Sara Pineda,

"não é somente um método de representação que aspira a criar um efeito mimético, é também um impulso contestador que 
obedece à característica de dar testemunho e fazer uma denúncia". (PINEDA, 2006, p. 43, tradução nossa) ${ }^{6}$

O caráter autobiográfico da obra pode ser compreendido a partir do que Philippe Lejeune define como autobiografia: "qualquer texto em que o autor parece expressar sua vida ou seus sentimentos, quaisquer que sejam a forma do texto e o contrato proposto por ele" (LEJEUNE, 2008, p. 53). O pesquisador francês também acrescenta a esta definição o conceito elaborado por Gustave Vapereau, na obra Dictionnaire universal des littératures (1876), cuja acepção de autobiografia no âmbito literário se refere a qualquer obra de literatura, em prosa ou em verso, em que o autor conta sua vida. No entanto, conforme nos alerta Magda Portal em sua Autobiografia, "é impossível captar - e revelar - a vida retrospectivamente, se não for para inventá-la de novo. Seu transcorrer nos escapa como água entre os dedos. Nas memórias, mais que a verdade, o que se impõe é a fantasia." (PORTAL, 2017, p. 40, tradução nossa) ${ }^{7}$. Assim, a partir dessa tensão entre o vivido e o narrado é que tomamos esta narrativa como um experimento autobiográfico do autor, porém recordando sempre os limites de cada afirmação autoral. Na passagem abaixo é possível vislumbrar alguns aspectos dessa forma de narrar:

E, como assim, você veio até a China?, lembro que Liu me perguntou [...] No começo deste ano, respondi, sim, de 1977, a Universidade de Educação La Cantuta, onde eu atuava como professor de Língua e Literatura, foi tomada de assalto pelos sinchis, um grupo especial da polícia com treinamento militar de comando. Como eu não estava de acordo com aquela medida violenta contra a academia, optei por sair [...]. (REYNOSO, 2006, p. 125, tradução nossa) ${ }^{8}$

\footnotetext{
6 "No es solo un método de representación que aspira a crear un efecto mimético, es también un impulso concursante que obedece a la característica de dar testimonio y hacer denuncia."

7 "Es imposible capturar - y revelar - la vida retrospectivamente, si no inventarla de nuevo. Su paso se nos escapa como el agua entre los dedos. En los recuerdos, más que la verdad, lo que se impone es la fantasía”.

8 “¿Y cómo así vino a China?, recuerdo que me preguntó Liu (...) A comienzos de este año, le contesté, sí, de 1977, la Universidad de Educación La Cantuta donde yo era profesor de Lengua y Literatura fue tomada por asalto por los Sinchis, un cuerpo especial de la policía con entrenamiento militar de comando. Como yo no estaba de acuerdo con tal medida de fuerza que violaba la inteligencia, opté por retirarme (...)". (REYNOSO, 2006, p. 125)
} 
Alguns estudiosos percebem que, após a experiência do exílio, a prosa de Reynoso pode ser lida dentro de uma segunda incursão criativa, que, segundo Christian L. R. Torres (2016), em seu livro Xuéxí. Formación y aprendizaje en Los Eunucos Inmortales y Babel, el paraíso de Oswaldo Reynoso y Miguel Gutiérrez, seria caracterizada por uma linguagem marcadamente poética e intimista, que visava à reflexão e ao descobrimento da identidade (tanto nacional como pessoal), em consonância com sua busca ética. Se em suas obras anteriores buscava-se a liberdade, entendida como corolário da consecução da revolução do proletariado, Reynoso muda o objeto de sua procura vital após a frustração com as tentativas fracassadas de efetivação de um regime aos moldes maoístas. A liberdade passa, então, a ser entendida como felicidade, fruto de uma nova proposição de pátria literária.

O romance inicia no dia 12 de maio, quando o narrador relata seu encontro com Liang, um estudante chinês que conhecera no país, em uma avenida movimentada na qual os estudantes em greve passavam em direção à Praça Tian'anmen, epicentro das manifestações contra o governo. Ao se despedir do amigo, o narrador sobrepõe a descrição da multidão de estudantes grevistas em Pequim com aquela da Rebelião de Arequipa, em 1950. A rebelião é provocada após uma greve de estudantes do Colégio Nacional da Independência Americana que, ao protestarem contra a ditadura do general Manuel A. Odría, são atacados por tropas militares.

E ele correu atlético e jovem até a calçada da Avenida da Ponte Branca. Seu jeans descolorido e sua camisa amarela começaram a se diluir entre as várias colunas de estudantes que passavam gritando, em frente às altas e maciças grades do Hotel da Amizade rumo à Praça Tian'anmen. [...] e a multidão se afastava sob a sombra das frondosas árvores salpicadas de brilhos vespertinos que reverberavam nos paredões amarelos do convento de Santa Catalina e avancei com a multidão que protestava contra $o$ massacre de alunos do Colégio da Independência até a prefeitura, quando, pelo lado de San Lázaro apareceu em tropel um pelotão da Guarda Civil Montada, que arremeteu com as espadas levantadas e ninguém correu. Resistiram sem arredar o pé, com paus e pedras gritando: Abaixo a ditadura! Morte aos assassinos! (REYNOSO, 2006, p. 113, tradução nossa). ${ }^{9}$

\footnotetext{
9 "Y corrió atlético y joven hasta la calzada de la Avenida del Puente Blanco. Su bluyín desteñido y su camisa amarilla comenzaron a diluirse entre las abigarradas columnas de estudiantes que pasaban gritando frente a las altas y macizas rejas del Hotel de
} 
No que se refere ao primeiro ponto de inflexão do romance analisado neste trabalho, o paralelo presente na descrição dos eventos violentos em ambas as cidades, observa-se no trecho como a construção da narrativa é costurada de forma a não separar onde acaba uma memória e se inicia a outra. A impossibilidade de se precisar os limites de cada evento suscita algumas reflexões. Sabemos que a violência do Estado autoritário independe das fronteiras geográficas e culturais; assim, não importa quem eram aqueles que lutavam contra a repressão do Estado, mas sim como, frente ao autoritarismo, o indivíduo submetido à violência reage como pode.

O paralelismo da escrita com a realidade encontra sua expressão na revelação frustrada da experiência de estar num país no qual se vislumbrou encontrar o sonho, que consistia numa sociedade aberta e livre, sufocado na realidade de uma sociedade maoísta violenta e autoritária. Mas, talvez, mais que um paralelismo, estamos frente a uma escrita que se inscreve sobre o rascunho de outra, um palimpsesto, como se uma realidade tomasse forma sobre os restos de uma outra passada, porém nunca terminada, que se manifesta na intermitência dos tempos verbais oscilando entre o pretérito imperfeito e o perfeito. Nessa sobreposição de memórias e eventos, o traço ficcional reafirma sua íntima dissociação entre o verbo e a realidade, tornada possível mediante certos recursos escriturais.

Outro exemplo do mesmo procedimento pode ser observado na passagem abaixo, na qual o narrador juntamente com seus colegas caminha em direção à Praça na qual os grevistas se concentram, quando, ao sentir o calor provocado pelo sol, projeta a memória do que irá viver quando retornar ao Peru:

E avançamos com a multidão pela ampla calçada sob a sombra das grandes copas das árvores até a Avenida da Paz Celestial, e faz calor e vivo através de todos meus poros e tenho que cauterizar para sempre a úmida e ardente ferida de solidão e abandono que começou a me devorar quando cheguei à China, e voltarei ao

la Amistad rumbo a la Plaza Tian'anmen. (...) y la muchedumbre se alejaba bajo la sombra de frondosos árboles salpicada de destellos vespertinos que reverberaban en los paredones amarillos del convento de Santa Catalina y avancé con la multitud que protestaba contra la masacre de alumnos del Colegio de la Independencia hacia la Prefectura cuando por el lado de San Lázaro apareció en tropel un pelotón de la Guardia Civil Montada que arremetió con el sable desenvainados y nadie corrió. Se resistió a pie firme con palos y piedras gritando: ¡Abajo la dictadura! ¡Muerte a los asesinos!” 
Peru e caminharei em pleno sol por La Colmena entre espelhos quebrados e comerciantes de bugigangas e loucos nus imundos e meninos drogados [...] fugindo atordoados dos potentes jatos de água e dos gases lacrimogêneos lançados pela polícia [...]. (REYNOSO, 2006, p. 191, tradução nossa) ${ }^{10}$

A lembrança é ativada através de um estímulo sinestésico, ao se associar à sensação provocada pelo clima de ambas as cidades. $\mathrm{O}$ paralelismo entre os eventos violentos também permanece, contudo, projetado a um embate futuro que o narrador sabe que irá ocorrer quando retornar ao Peru. O que não está dito, mas pressuposto, sobre o futuro conflito que espera nosso escritor em seu regresso ao país natal é que, contrariamente ao paralelo que traça no texto, deverá dissociar as duas experiências em suas conclusões políticas e pessoais. Efetivamente, Reynoso enfrentou uma recepção hostil entre intelectuais próximos quando regressou, uma vez que foi acusado de estar ausente num momento histórico - a possível libertação do Peru pelas forças revolucionárias de Sendero Luminoso, com quem pessoalmente simpatizava - o que vai aparecer de algum modo em seus textos futuros, que se dirigem a discutir assuntos pessoais e cada vez menos ideológicos. Ou seja, muito mais que no mundo exterior que o cerca, será nas páginas de sua ficção a arena na qual o escritor vai enfrentar suas batalhas mais aguerridas.

Na passagem também é possível observar as marcas do exílio no narrador, que afirma possuir uma "ferida de solidão e abandono" desde que chegou à China. Para a pesquisadora Daisy César (2008, p. 141), o sentimento de dor e angústia é reflexo da experiência do exílio, que traz à tona o conflito do sujeito que, ao mesmo tempo em que tenta se desligar do passado e das tradições, sofre com a culpa por se desprender de suas raízes. Todo esse processo, de reconstrução do próprio indivíduo e da sua relação com o país de origem, processados no distante país que o acolheu, implica profundas mudanças na maneira como ele perceberá a própria identidade.

\footnotetext{
10 "Y avanzamos con la multitud por la amplia acera bajo la sombra de los coposos árboles hacia la Avenida de la Paz Celestial y hace calor y vivo a través de todos mis poros y tengo que cauterizar para siempre la húmeda y ardiente herida de soledad y de derrumbe que comenzó a devorarme cuando llegué a China y volveré al Perú y caminaré en pleno sol por La Colmena entre espejos rotos y comerciantes de baratijas y mugrientos locos desnudos y niños drogaditos (...) huyendo atolondrados de potentes chorros de agua y gases lacrimógenos lanzados por policías (...)"
} 
O segundo ponto que reclama nossa atenção é a relação estabelecida com o estrangeiro no romance. Nota-se que em diversos momentos o narrador discute como a cultura chinesa se relaciona com o mundo ocidental a partir do distanciamento e da desconfiança, em uma relação ambivalente. Em um primeiro plano, tem-se os aspectos intrínsecos à cultura chinesa que se refletem no tratamento mais reservado e na manutenção de uma postura misteriosa frente ao estrangeiro, como se pode depreender da passagem: "para os ocidentais parece muito difícil conhecer a fundo muitas coisas importantes da China, porque não podem penetrar nos insondáveis mistérios de nossa milenar cultura asiática" (REYNOSO, 2006, p. 142, tradução nossa) ${ }^{11}$.

Se aos olhos do Oriente, a imagem do estrangeiro historicamente aparece relacionada aos desejos expansionistas coloniais ou imperiais dos países ocidentais centrais, a postura crítica do narrador irrompe contra estes estereótipos, vinculando a operação com as desiguais miradas que este mesmo centro ocidental dedica aos países que compõem sua periferia: "Entre alguns deles e eu há a diferença de uma preposição, acrescentei. Como? ele se surpreendeu, curioso. Eu vivo na China e eles vivem da China"; e salienta que "essa atitude prepotente do estrangeiro ocidental na China é a mesma do imigrante europeu médio, ou do norteamericano estúpido, frente aos povos da América Latina" (REYNOSO, 2006, p. 214, tradução nossa) ${ }^{12}$.

Porém, como se desse um giro em seu próprio argumento, o narrador declara sua desconfiança de que essa postura possa também ser resultado de uma construção ideológica que visa à preservação do próprio regime autoritário, o que delata o olhar crítico de um intelectual que não cessa de interpelar a realidade em suas diversas interpretações:

[...] esta economia de intimidades [dos chineses] não apenas se deve à secular desconfiança que sentem dos estrangeiros no fundo de sua alma [...], mas também - e isso é o mais grave - a uma pervertida formação ideológica que se esmera em apresentar todo

\footnotetext{
11 "a los occidentales se les hace muy difícil conocer a fondo muchas cosas importantes de China, porque no pueden penetrar en los insondables misterios de nuestra milenaria cultura asiática"

12 "Entre algunos de ellos y yo hay la diferencia de una preposición, agregué. ¿Cómo?, se extranó curioso. Yo vivo en China y ellos viven de China"; e salienta que "esa actitud prepotente del extranjero occidental en China es la misma que tiene el imigrante europeo medio o el norteamericano estúpido frente a los pueblos de América Latina”.
} 
estrangeiro como um foco de alta contaminação burguesa e podre, cujo contato ou influência é castigado severamente pelos eunucos imortais. (REYNOSO, 2006, p. 144-145, tradução nossa) $)^{13}$

Em entrevista, Reynoso explica que o significado de eunucos imortais se refere aos "burocratas do poder, aqueles personagens que sempre estão atrás do Estado, independentemente de quem os controle" (REYNOSO, 1996 apud HEREDIA, 2013, p. 330). Os eunucos imortais se referem aos agentes que atuam por trás e por dentro do regime oficial, pertencentes a uma longa linhagem de grupos de poder que se utilizam da máquina pública para alcançar seus interesses. Nessa perspectiva, a construção de um imaginário simbólico que associe a imagem do estrangeiro à decadência de um sistema capitalista corrompido cumpre sua função de isolar o país das influências liberais e forjar uma condição pura e intacta da cultura chinesa.

O último ponto a ser revisto no romance refere-se ao viés antropológico adotado na narrativa para se pensar a pátria, a identidade e a cultura. Primeiramente, interessa-nos considerar a experiência da falta de lugar e do desamparo do sujeito exilado, expropriado da sua terra natal. Edward Said (2003) sustenta que o lugar do intelectual exilado é ambíguo, pois, ao mesmo tempo em que sofre com o abandono da terra natal, tem a oportunidade (e a liberdade) de conhecer uma pluralidade de lugares que somente seriam acessados pelo intercâmbio forçado. E na difícil tarefa de elaboração da solidão do exílio, a criação literária pode funcionar como estratégia, como observado na obra de Reynoso.

O narrador elabora o desamparo e sua solidão causados pelo sentimento de falta de lugar, a princípio, negando sua identidade original, isso é, a pátria:

E como [poderei encontrar a felicidade]? Voltei a perguntar. O noviço falou e Lian traduziu: diz que seguindo o caminho mais sábio da vida, quer dizer, fazer o que se tem de fazer para ser o que se tem de ser. Em qualquer parte do mundo? O noviço Lin, colocando sua generosa mão em meu joelho falou e logo Lian

13 “(...) esta avaricia de intimidades [de los chinos] no solo se debe a la secular desconfianza que sienten en la profundidad de su sangre a los extranjeros (...) sino también y esto es lo más grave a una pervertida formación ideológica que se esmera en presentar a todo extranjero como un foco de la alta contaminación burguesa y podrida cuyo contacto o influencia es castigado severamente por Los Eunucos Inmortales." 
traduziu: Em sua pátria. E eu lhe disse: Nunca experimentei o sentimento de pátria. (REYNOSO, 2006, p. 178, tradução nossa) ${ }^{14}$

O "sentimento de pátria" nunca experimentado pelo narrador não pode ser entendido como uma negação da tristeza da partida ou da nostalgia das memórias vividas no Peru, mas uma nova formulação que abarque sentimentos contraditórios suscitados durante o período fora de seu país. Especialmente por se tratar de um autoexílio, isso é, uma escolha consciente de sair de seu lugar de origem, as questões relacionadas aos sentimentos de pertencimento ou de herança cultural herdada ganham mais complexidade. Quando o narrador afirma que

[...] ocorre que sempre me pareceu grotesco o sentimento de pertencimento a uma pátria de papel, ainda mais quando vem acompanhado de comidas e hinos e bandeiras. [...] minha pátria seria o rosto das pessoas que amo ou talvez sempre amei, a pátria que não existe, por isso que nunca consegui encontrar a felicidade plena. Talvez eu seja um exilado do paraíso e, no Templo da Nuvem Branca, o noviço Lin me disse: a pátria que não está em nenhuma parte, essa é minha verdadeira pátria. (REYNOSO, 2006, p. 168-169, tradução nossa) $)^{15}$

O que faz é negar a construção simbólica de identidade e cultura nacional a partir de elementos associados afetivamente a um país, como constituintes de sua gastronomia, natureza, folclore, artesanato, tudo o que possa reduzi-lo a um bem simbólico ou a um produto de mercado.

Em uma das citações de Los Eunucos Inmortales, o poeta russo Ievguêni Ievtuchenko afirma que "a pátria não é um termo geográfico ou literário, mas a imagem de homens vivos" (IEVTUCHENKO apud POLAR,

14 “¿Y cómo [podré encontrar la felicidad]?, volví a preguntar. El novicio habló y Lian tradujo: Dice que siguiendo el camino más sabio de la vida, es decir, hacer lo que se tiene que hacer para ser lo que tiene que ser. ¿En cualquier parte del mundo? El novicio Lin poniendo su generosa mano en mi rodilla habló y luego Lian tradujo: En tu patria. Y yo le dije: Nunca he experimentado el sentimiento de patria."

15 “(...) sucede que siempre me ha parecido grotesco el sentimiento de añoranza por una patria de papel y más aún cuando viene unido a comidas o a himnos y banderas. (...) mi patria sería el rostro de la gente que amo o tal vez siempre he amado la patria que no existe, por eso es que nunca he podido encontrar la clave de la felicidad. A lo mejor, soy un exiliado del paraíso y en el Templo de la Nube Blanca, el novicio Lin me dice: La patria que no está en ninguna parte esa es mi verdadera patria". 
1986, p. 58, tradução nossa $)^{16}$. Na mesma direção, em entrevista a Enrique Planas, Reynoso ratifica essa perspectiva, ao afirmar que “(...) não são os costumes nem a culinária que dão identidade a um país, mas o olhar e $o$ sorriso dos jovens." (REYNOSO, 2011, p. 40, tradução nossa) ${ }^{17}$. No entanto, ao contrastar ambas as afirmações que se corroboram ao longo do romance, seria prudente analisar não apenas as similitudes que guardam cada um dos postulados, mas suas diferenças, frente ao universo autoritário dos mundos comunistas russo e chinês. Ievtuchenko fala a partir de um mundo em decomposição, o Estado soviético totalitário que Stálin construiu sob os fundamentos do terror e que, a partir da abertura política que tem início com Mikhail Gorbatchov nos anos oitenta, termina com a exaustão do próprio sistema; Reynoso está postado justo no epicentro do Estado comunista maoísta, também totalitário e violento, porém, em plena vigência econômica, o que lhe permite ocupar um lugar de prestígio no tabuleiro político mundial.

A construção de uma noção antropológica de pátria está diretamente relacionada com a decepção com o regime implementado na China: "Eu também [fui uma vítima da Revolução Cultural]: os quatro me enganaram" (REYNOSO, 2006, p. 247, tradução nossa) ${ }^{18}$. A pátria ideal sedimentada sob os preceitos da teoria maoísta, de uma democracia social e igualitária, vislumbrada por tanto tempo e projetada na opção pelo autoexílio na China, desaparece com a constatação de que o regime era apenas uma vitrine de luxo, que ocultava as reais condições de vida dos chineses (REYNOSO, 2006, p. 245).

A frustração com os rumos tomados pelo governo após a Revolução Cultural Chinesa desperta no narrador um misto de sentimentos que passa pela desesperança, o medo, pânico, solidão e queda, como se pode observar na passagem:

Deixei o restaurante e caminhei pela rua-galeria tentando aliviar essa sensação de desesperança, mas quando reconheci neste refúgio a construção real e tangível do labirinto de túneis (...) que apareciam desde minha juventude em meus sonhos recorrentes, essa desesperança se transformou em medo, e quando compreendi que não se tratava de sonhos premonitórios, mas efetivamente estava no centro exato do dédalo de meus pesadelos (...) esse medo aumentou, e quando descobri que o problema não estava em saber distinguir o limite entre sonho e realidade, já que

\footnotetext{
16 "La patria no es un término geográfico o literario, sino la imagen de hombres vivos" 17 "(...) no son las costumbres ni la comida lo que dan la identidad de un país, sino la mirada y la sonrisa de los jóvenes."

18 "Yo también [fui una víctima de la Revolución Cultural]: la cuatrinca me engañó"
} 
o refúgio em Pequim e o labirinto dos meus sonhos eram a mesma construção (...) esse medo se converteu em pânico e foi a primeira vez que senti essa sensação de solidão e abandono que, ao longo da minha estadia na China, afligiu meus sonhos. (REYNOSO, 2006, p. 231) $)^{19}$

Sobre a decepção com o espaço imaginado durante o exílio, Gabeira (2015) afirma que, no exílio, um lugar se perde no caminho e nunca se volta para o país dos sonhos, já que o país muda, e o sujeito também. No caso de Los Eunucos Inmortales, a frustração não se dá com o país de origem, idealizado e por isso nunca reencontrado mesmo após o retorno. No romance, a pátria de acolhida (e o regime político) idealizada não se efetiva e a desconstrução do Estado imaginado implica a desilusão com o próprio desterro. Quando já não fazem sentido as motivações que o levam a se autoexilar, todo o processo de adaptação, seus conflitos, suas crenças e traumas também são postos em xeque.

Indursky e Conte (2015, p. 279), ao comentarem a relação exílio e frustração, afirmam que

no exílio é manifesta a referência à frustração e todo seu mote de reivindicação imaginária sobre algo que seria retirado do sujeito por uma instância simbólica, como a autoridade do Estado, e logo investida pelo sujeito na ordem do Real: materializada na terra perdida.

No romance, essa sensação é ainda mais grave, uma vez que a ambivalência na simbologia geográfica do exílio (paraíso perdido/terra prometida) sofre uma dupla perda (não tenho pátria/não reconheço o país que me acolhe).

$\mathrm{O}$ professor $\mathrm{O}$ responde à decepção com uma nova motivação vital: encontrar a felicidade. Para Torres (2016), a busca por um ideal, um estado emocional, ou um encontro com seu eu justificaria o autoexílio como forma de encontrar a si mesmo. E é nesse aspecto que se deve pensar a perspectiva antropológica adotada no livro. Em detrimento de

19 "Dejé el restaurante y caminé por la calle-galería tratando de aliviar esa sensación de desesperanza pero cuando reconocí en este refugio la construcción real y tangible del laberinto de túneles (...) que aparecían desde mi juventud en mis sueños recurrentes esa desesperanza se transformó en miedo, y cuando comprendí que no se trataba de sueños premonitorios sino que efectivamente estaba en el centro mismo del dédalo de mis pesadillas (...) ese miedo se acrecentó y cuando descubrí que el problema no estaba en saber distinguir el límite entre sueño y la realidad, puesto que el refugio de Beijing y el laberinto de mis pesadillas eran la misma construcción (...) ese miedo se convirtió en pánico y fue la primera vez que sentí esa sensación de soledad y de derrumbe que a lo largo de mi estadía en China ha afligido mis sueños." 
quaisquer questões doutrinárias ou políticas, a felicidade não poderia estar atrelada a nenhum elemento que não o estritamente humano: a curiosidade, o riso, o olhar... E isso recuperaria o sentido da experiência vivida na China, como observado na epígrafe do romance:

Quando comecei a escrever este romance, acreditava firmemente que havia ido à China buscar a felicidade: quando o terminei, compreendi que não era a felicidade o que buscava, mas a verdade, e essa verdade a encontrei na felicidade por tê-lo escrito. (REYNOSO, 2006, p. 111, tradução nossa) ${ }^{20}$

Aqui Reynoso revela que a felicidade não se encontrava em nenhuma parte esperando que o narrador a descobrisse; não, a felicidade surgia nas páginas escritas, a pátria tomava forma a partir das palavras, a realidade finalmente ganhava contorno no traçado que as palavras iam impondo sobre a superfície branca da página, tomando sua tinta do caudal de suas memórias.

\section{Considerações Finais}

Este artigo buscou realizar uma análise de alguns elementos constitutivos do romance autobiográfico Los Eunucos Inmortales de Oswaldo Reynoso, que dialogam com o segundo período criativo da sua produção literária após o autoexílio. A partir do paralelismo entre Lima e Pequim na rememoração dos eventos violentos em ambas as cidades, da construção da relação ambivalente dos chineses com estrangeiro ao longo da obra e da noção de pátria a partir de um olhar desmistificador antropológico, é possível pensar numa leitura da obra que reflita sobre o conceito de nação, pátria literária e exílio.

Ao reformular a identidade nacional desde os aspectos literários, Reynoso engendra uma nova perspectiva sobre o próprio conceito de nação, no qual se põe em xeque a validade dos traços socialmente compreendidos como símbolos representativos de determinado país. Na mesma lógica, Flora Sussekind (1984), em seu livro Tal Brasil, qual romance?, sustenta que a noção de identidade não é uma condição posta, acabada, nem tampouco imutável; trata-se de um efeito, isso é, a identidade nacional resulta de diferentes condicionantes sob determinada ótica. Tal revisão conceitual implica considerar que a identidade enquanto

\footnotetext{
20 "Cuando comencé a escribir esta novela, creía firmemente que había ido a China a buscar la felicidad: cuando la terminé, comprendí que no era la felicidad que buscaba, sino la verdad, y esa verdad la he encontrado en la felicidad de haberla escrito."
} 
potência de unidade coletiva é variável e não inocente, uma vez que é operada sob a lógica do interesse social, econômico e político. Nesse sentido, a defesa de uma pátria literária como sua nação de origem reflete o rechaço pelos símbolos nacionais forjados pela ótica progressista, modernizadora, desigual e excludente, tanto na América Latina quanto na China.

Para o autor, a literatura é a ótica que deve predominar sobre as formulações que resultariam nas novas identidades nacionais às quais ele (e sua produção) se filiariam. A literatura, nesse contexto, como afirma Wander Melo Miranda (2010, p. 173), é a forma limiar de representação social e de redimensionamento cultural e político que revelaria a identidade não como estigma, mas como possibilidade de sentidos e valores.

\section{Referências}

CÉSAR, Daisy. A contística de Sonia Coutinho e suas implicações identitárias. Caderno de Letras da UFF, Niterói, n. 36, p. 133-143, 1. sem. 2008.

ECO, Umberto. Interpretação e superinterpretação. São Paulo: Martins Fontes, 1993.

ESLAVA, Jorge. Oraciones del Cuerpo. In: REYNOSO, Oswaldo. Narraciones 1. Lima: Editorial Universidad Ricardo Palma, 2005. p. 9-22.

GABEIRA, Fernando. Notas sobre o exílio interior. $O$ Globo, Rio de Janeiro, 22 fev. 2015. Segundo Caderno.

HEREDIA, Gladys Flores (org.). Oswaldo Reynoso: Los universos narrativos I. Lima: Editorial San Marcos, 2013.

INDURSKY, Alexei Conte; CONTE, Bárbara de Souza. Trabalho psíquico do exílio: o corpo à prova da transição. Ágora, Rio de Janeiro, v. 18, n. 2, p. 273-288, jul./dez. 2015. DOI: https://doi.org/10.1590/S151614982015000200008 .

LEJEUNE, Philippe. O pacto autobiográfico: de Rousseau à Internet. Belo Horizonte: Editora UFMG, 2008.

MIRANDA, Wander Melo. Nações literárias. São Paulo: Ateliê Editorial, 2010.

PINEDA, Sara R. El proyecto literario de Narración. In: REQUEJO, Néstor T. El grupo Narración en la literatura peruana. Lima: Arteidea, 2006. p. 35-52. 
PLANAS, Enrique. Un lugar donde colocar el sentimiento de mi inocencia. In: REYNOSO, Oswaldo. Editado por Enrique Planas. El tesoro de la juventud. Lima: Estruendomudo, 2011. p. 8-17.

POLAR, Antonio Cornejo. (org.). Primer encuentro de narradores peruanos. Lima: Latinoamericana Editores, 1986.

PORTAL, Magda. La vida que yo viví... Autobiografía de Magda Portal. Lima: Casa de la Literatura Peruana, 2017.

REYNOSO, Oswaldo. El goce de la piel. Lima: San Marcos, $2005 \mathrm{~b}$.

REYNOSO, Oswaldo. Los Eunucos Inmortales. In: REYNOSO, Oswaldo. Narraciones 2. Lima: Editorial Universidad Ricardo Palma, 2006. p. 105-350.

REYNOSO, Oswaldo. Narraciones 1. Lima: Editorial Universidad Ricardo Palma, 2005a.

REYNOSO, Oswaldo. Oswaldo Reynoso, declarado inocente. [Entrevista concedida a] Enrique Planas. In: REYNOSO, Oswaldo. Edição de Enrique Planas. El tesoro de la juventud. Lima: Estruendomudo, 2011. p. 36-49.

SAID, Edward. Reflexões sobre o exílio. In: SAID, Edward. Reflexões sobre o exílio e outros ensaios. São Paulo: Companhia das Letras, 2003. p. 46-60.

SARTRE, Jean-Paul. Prefácio. In: FANON, Frantz. Os condenados da terra. Rio de Janeiro: Civilização Brasileira, 1961. p. 1-21.

SUSSEKIND, Flora. Tal Brasil, qual romance? Rio de Janeiro: Achiamé, 1984.

TORRES, Christian L. R. Xuéxí. Formación y aprendizaje en Los Eunucos Inmortales y Babel, el paraíso de Oswaldo Reynoso y Miguel Gutiérrez. Lima: Editora PUC Perú, 2016.

VIGIL, Ricardo González. Años decisivos de la narrativa peruana. Lima: San Marcos, 2008. 